Pesq. Vet. Bras. 36(5):363-372, maio 2016 DOI: $10.1590 /$ S0100-736X2016000500002

\title{
Distribution of lymphocytes, immunoglobulin-containing cells, macrophages, and dendritic cells in the accessory sex glands of rams experimentally infected with Actinobacillus seminis ${ }^{1}$
}

\author{
Jorge Acosta-Dibarrat ${ }^{2 *}$, Víctor Tenorio-Gutiérrez ${ }^{3}$, Edgardo Soriano-Vargas², \\ Martín Talavera-Rojas ${ }^{2}$, Luis Cal-Pereyra ${ }^{4}$, Roberto Montes de Oca Jiménez ${ }^{2}$, \\ Valente Velázquez-Ordoñez ${ }^{2}$ and Jorge Tórtora-Pérez ${ }^{5}$
}

\begin{abstract}
Acosta-Dibarrat J., Tenorio-Gutiérrez V., Soriano-Vargas E., Talavera-Rojas M., Cal-Pereyra L., Montes de Oca-Jiménez R., Velázquez-Ordoñez V. \& Tórtora-Pérez J. 2016. Distribution of lymphocytes, immunoglobulin-containing cells, macrophages, and dendritic cells in the accessory sex glands of rams experimentally infected with Actinobacillus seminis. Pesquisa Veterinária Brasileira 36(5):363-372. Centro de Investigación y Estudios Avanzados en Salud Animal, Facultad de Medicina Veterinaria y Zootecnia, Universidad Autónoma del Estado de México, Km 15.5 Carretera Toluca-Atlacomulco, Toluca, ME 50100, México. E-mail: jpacosta00@hotmail.com

The distribution of cells involved in the immune response in accessory sex glands of rams experimentally infected with Actinobacillus seminis was studied. Twelve one-year old rams were experimentally infected by intraurethral (IU) $(n=4)$ and intraepididymal (IE) $(n=4)$ route, and four control (CON) animals were used. The animals were slaughtered 35 days post-inoculation, samples were taken from accessory sex glands, and bacteriology and histopathology tests were performed. The presence of CD4, CD8 and TCR $\gamma \delta$ (WC1) lymphocytes, CD45RO cells, macrophages (CD14), dendritic cells (CD1b), IgA-, IgG- and IgM-containing cells (IgCC) was determined. Animals of the IE group developed clinical epididymitis. No lesions were seen in rams of the IU group; two of the intraepididymal inoculated CON developed small lesions in the epididymis. A. seminis isolates were achieved from 6:16 (37.5\%) accessory sex glands in the IE group, but not in the IU and CON groups. In the CON group, IgA- and IgM- containing cells predominated in the bulbourethral glands and the disseminated prostate, and they were scarce or null in the vesicles and ampullae. A significant increase of IgA-, IgG- and IgM- containing cells was confirmed in the seminal vesicles, the ampullae and the bulbourethral glands in the IE group. In the IE and IU groups, an increase in CD4, CD8, WC1, CD45R0 and CD14 was evidenced in the vesicles and ampullae. CD1b dendritic cells were present in the ampullae and vesicles with inflammatory processes. A. seminis triggered a local immune response in the IE and IU groups. These results indicate a different pattern of infiltrating immune cells in the accessory sex glands of infected $A$. seminis rams.
\end{abstract}

INDEX TERMS: Accessory sex glands, rams, Actinobacillus seminis, lymphocytes, immunoglobulincontaining cells, macrophages.

RESUMO.- [Distribuição de linfócitos, células carreadoras de imunoglobulinas, macrófagos e células dendríticas em glândulas sexuais acessórias de carneiros

\footnotetext{
${ }^{1}$ Received on October 30, 2015.

Accepted for publication on February 15, 2016

${ }^{2}$ Centro de Investigación y Estudios Avanzados en Salud Animal, Facultad de Medicina Veterinaria y Zootecnia, Universidad Autónoma del Estado de México, Km 15,5 Carretera Toluca-Atlacomulco, Toluca, ME 50100, México. *Corresponding author: jpacosta00@hotmail.com

${ }^{3}$ Centro Nacional de Investigación Disciplinaria Microbiología (CENID-
}

infectados experimentalmente com Actinobacillus seminis.] A distribuição das células envolvidas na resposta imune em glândulas sexuais acessórias de carneiros expe-

\footnotetext{
-Microbiología) INIFAP, Km 15,5 Carretera Federal México, Toluca, Col. Palo Alto, DF 05110, México.

${ }^{4}$ Departamento de Patología, Facultad de Veterinaria, Universidad de la República, Alberto Lasplaces, 1550, Montevideo, MO 11600, Uruguay.

${ }^{5}$ Facultad de Estudios Superiores Cuautitlán, Universidad Nacional Autónoma de México, Km 2,5 Carretera Cuautitlán-Teoloyucan, Cuautitlán Izcalli, ME 54714, México.
} 
rimentalmente infectados com Actinobacillus seminis foi estudada. Doze carneiros de um ano de idade foram experimentalmente infectados via intrauretral (IU) $(n=4)$ e via intraepididimal (IE) $(n=4)$ e quatro animais controles (CON) foram utilizados. Os animais foram abatidos 35 dias após a inoculação, amostras foram retiradas das glândulas sexuais acessórias e testes bacteriológicos e histopatológicos foram realizados. A presença de linfócitos CD4, CD8 e TCR $\gamma \delta$ (WC1), células CD45R0, macrófagos (CD14), células dendríticas (CD1b) e células contendo IgA, IgG and IgM (IgCC) foi determinada. Os animais do grupo IE desenvolveram epididimite clínica. Não foram visualizadas lesões nos carneiros do grupo IU, dois dos CON inoculados intraepididimalmente desenvolveram pequenas lesões no epidídimo. Isolados de $A$. seminis foram obtidos de 6:16 (37,5\%) nas glândulas sexuais acessórias no grupo IE mas não nos grupos IU e CON. No grupo CON células contendo IgA and IgM predominaram nas glândulas bulbouretrais e na próstata e foram escassas ou ausentes nas vesículas e na ampola. Um incremento significativo de células contendo IgA, IgG and IgM foi confirmado nas vesículas seminais, na ampola e nas glândulas bulbouretrais no grupo IE. Nos grupos IE e IU foi evidenciado um aumento em CD4, CD8, WC1, CD45R0 e CD14 nas vesículas e ampola. As células dendríticas CD1b estavam presentes na ampola e nas vesículas com processo inflamatório. A. seminis induziu uma resposta imune local nos grupos IE e IU. Estes resultados indicam um padrão diferente de células imunes infiltrantes nas glândulas sexuais acessórias de carneiros infectados por A. seminis.

TERMOS DE INDEXAÇ̃̃O: Glândulas sexuais acessórias, carneiros, Actinobacillus seminis, linfócitos, células carreadoras de imunoglobulinas, macrófagos.

\section{INTRODUCTION}

Sheep epididymitis has been mainly associated with Brucella ovis and Actinobacillus seminis infections (Burgess 1982, Moustacas et al. 2013). The pathogenesis of the disease caused by $A$. seminis has been explored to a small extent; the presence of pathogenicity factors in A. seminis, such as adhesins (Healey et al. 1991) or RTX toxins (Schaller et al. 2000 ), is likely to contribute to the development of the pathology. However, the susceptibility to infection of the accessory sex glands, especially of the seminal vesicles in sheep (Foster et al. 1987, Al-Katib \& Dennis 2005, Acosta-Dibarrat et al. 2006), bulls (Bagshaw \& Ladds 1974, Cavalieri \& Van Camp 1997), and humans (Furuya et al. 2004), leads us to believe that other factors, especially immunological factors, would be implicated in such susceptibility.

The male genital tract has to accomplish functions of defense against infections, and it must also tolerate germ cells that present differential antigens. Recently, the study of the immune response mechanisms in the reproductive system has been intensified, focused on the fight against sexually transmitted diseases (Anderson \& Pudney 1999).

The information on the immune response mechanisms in the male reproductive tract in different species, and particularly, the information on the presence and distribution of immune response cells in the reproductive tract of she- ep, is limited (Acosta-Dibarrat et al. 2007, 2014, Moustacas et al. 2014). In this work, rams were experimentally infected with A. seminis intraurethral (IU) and intraepididymal (IE) inoculation, and the distribution and amount of CD4, CD8, and TCR $\gamma \delta$ lymphocytes, immunoglobulin-containing cells, macrophages, CD1b dendritic cells and CD45RO cells in the accessory glands were studied.

\section{MATERIALS AND METHODS}

Animals and Actinobacillus seminis inoculation. The animals were kept during the performance of the previous examine to slaughter facilities in the FES Cuautitlán UNAM. Inoculation, sampling protocols and slaughter were endorsed by the Subcommittee Institutional Animal Care Experimentation (SICUAE) of the Faculty of Veterinary Medicine, UNAM. This protocol was approved by UNAM at $20 / 06 / 2003$.

Twelve one-year-old male Pelibuey sheep were used, from a flock without clinical history of the disease, with no clinical alterations, and with negative semen bacteriology and serology against $A$. seminis and B. ovis. Three groups of four animals each were formed. The first group was challenged with $A$. seminis by intraurethral (IU) route; the same suspension was intraepididymally (IE) administered to the second group, directly in the epididymal tail. Physiologic saline solution (PSS) was administered by IU intraurethral and in the epididymal tail to the third group, which remained as non-infected control (CON).

A. seminis ATCC 15768 strain was used as challenge bacterium; it was seeded in blood agar and cultured in PSS. The challenge inoculum had a bacterial concentration of $2.3 \times 10^{9} \mathrm{CFU} / \mathrm{ml}$.

Inoculation by IU route was carried out with $2 \mathrm{ml}$ of the bacterial suspension, with previous ablation of the urethral process under sedation, using urethral-probing catheters for cats. Inoculation by IE route was carried out following scrotum disinfection and cleaning, with $1.5 \mathrm{ml}$ of the bacterial suspension in the left epididymal tail, and $0.5 \mathrm{ml}$ were applied in the right tail. $1.5 \mathrm{ml}$ of PSS was administered to controls by intraurethral and intraepididymal route in the tail of the right epididymis.

Sample management. All animals were slaughtered at 35 days post-inoculation, and the seminal vesicles, the ampullae of the deferent duct, the bulbourethral glands and the pelvic urethra (including the disseminated prostate) were obtained.

Samples of the same regions were taken in all cases to perform histopathology, immunohistochemistry and bacteriology tests (Acosta-Dibarrat et al. 2007, 2014), using a sagittal section of the bulbourethral glands and the apical portion of the vesicles; the pelvic urethra was cross-sectionally cut at a site equidistant from the bulbourethral glands and the seminal vesicles. A medial section was obtained from the ampullae of the deferent duct at the zone equidistant from the deferent duct and its junction with the pelvic urethra. The immunohistochemistry and immunofluorescence samples were included in OCT-based cryopreservative from the Tissiu-Tek brand (Sakura Finetec, Torrance, USA) and were immediately frozen in liquid nitrogen, after passage over nitrogen vapors for 2 minutes, and were subsequently immersed. Samples were withdrawn from nitrogen and kept at $-80^{\circ} \mathrm{C}$ until sectioning.

Successive $4 \mu \mathrm{m}$ sections were performed with a HistoSTAT microtome (AO Scientific Instrument, New York, USA) and were mounted on plates treated with poly-L-Lysin (Sigma Chemical Co, St. Louis, USA), they were fixed with acetone for $10 \mathrm{~min}$. Four slices of approximately $1.0 \mathrm{~cm}^{2}$ were placed on each plate; one slice was used as control and the other three were used for the treatment with specific monoclonal antibodies. 
Table 1. Characteristics of the monoclonal antibodies used in immunohistochemistry tests

\begin{tabular}{|c|c|c|c|c|c|}
\hline Monoclonal & Specificity & Cell expression & $\begin{array}{c}\text { Animal origin } \\
\text { Isotype } \\
\text { Source }\end{array}$ & Dilution used & $\begin{array}{c}\text { Manufacturing } \\
\text { laboratory }\end{array}$ \\
\hline CC15 & WC1 & $\gamma / \delta$ lymphocytes & $\begin{array}{c}\text { Mouse } \\
\text { IgG2a } \\
\text { Supernatant }\end{array}$ & $1: 400$ & SEROTEC \\
\hline 17D1 & CD4 & Helper lymphocytes & $\begin{array}{l}\text { Mouse } \\
\text { IgG1 } \\
\text { Ascitic fluid }\end{array}$ & $1: 400$ & VMRD \\
\hline CC63 & CD8 & Cytotoxic lymphocytes & $\begin{array}{c}\text { Mouse } \\
\text { IgG2a } \\
\text { Supernatant }\end{array}$ & $1: 100$ & BIOSOURCE \\
\hline GC44A & CD45R0 & $\begin{array}{l}30 \% \text { mononuclear } \\
\text { and granulocytes }\end{array}$ & $\begin{array}{l}\text { Mouse } \\
\text { IgG3 } \\
\text { Supernatan }\end{array}$ & $1: 500$ & VMRD \\
\hline CC14 & CD1b & Dendritic cells & $\begin{array}{c}\text { Mouse } \\
\text { IgG1 } \\
\text { Ascitic fluid }\end{array}$ & $1: 100$ & BIOSOURCE \\
\hline VPM 65 & CD14 & Macrophages, monocytes & $\begin{array}{c}\text { Mouse } \\
\text { IgG1 } \\
\text { Supernatant }\end{array}$ & $1: 30$ & BIOSOURCE \\
\hline
\end{tabular}

Immunohistochemistry. Slices were hydrated with PBS for 10 minutes and endogenous peroxidase was blocked with Peroxo-Block (Lab. Zymed, San Francisco, USA) for 45 seconds. An unspecific blockade was carried out with $10 \%$ caprine serum overnight. Then, primary monoclonal antibodies for the different receptors were applied (Table 1), which were incubated for 2 hours at room temperature. The biotin-goat anti mouse IgG complex was subsequently applied (Lab. Zymed, San Francisco, USA) for 30 minutes; then, the Streptavidin-Peroxidase complex (Lab. Zymed, San Francisco, USA) was administered for 15 minutes; the DAB substrate (Lab. Zymed, San Francisco, USA) was applied until a reaction was observed (2 to 5 minutes) and hematoxylin contrast staining was carried out. Three washings with PBS were performed between each step. Finally, the slices were dehydrated, cleared and mounted.

In the control slice, the primary antibody was replaced with PBS. Additionally, plates with prepuce sections were used as positive control in all runs, since it had been previously confirmed that cells positive to all monoclonal antibodies used in this work were present in this organ.

Immunofluorescence. For the determination of immunoglobulin-containing cells (IgCC), tissue Igs were eliminated first by placing the plates in PBS all night; an unspecific blockade with $1 \%$ ASB was subsequently performed for 1 hour at room temperature, and three 5-minute washings with PBS were carried out. Anti-ovine IgA primary antibody (Bethyl Lab., Montgomery, USA) was applied in a 1:40 dilution, as well as anti-ovine IgG primary antibody (Bethyl Lab., Montgomery, USA) in a 1:200 dilution, and anti-ovine IgM primary antibody (Bethyl Lab., Montgomery, USA) in 1:60 in PBS with 1\% ASB. Incubation was performed for 1 hour at $37^{\circ} \mathrm{C}$. Three washings were performed and the secondary antibody, TRICT-conjugated anti-rabbit IgG antibody (Sigma-Aldrich, St Louis, USA), was applied in a 1:30 dilution (in 10\% goat serum and $1 \% \mathrm{ASB}$ ) for one hour at $37^{\circ} \mathrm{C}$. Finally, it was washed again 3 times for 5 minutes per washing, and was mounted in glycerin and observed under an epifluorescence microscope. The primary antibody was replaced with PBS in the control slice, and the technique described above was then followed. This control was included due to the possibility of unspecific labeling by the anti-rabbit IgG conjugate. In this case, a prepuce section was also used as positive control, on which positive labeling had been previously demonstrated for the three immunoglobulins.

Cell count and statistical analysis. Cell count was carried out in ten $40 \mathrm{X} 10 \mathrm{x}$ fields with the Image Pro Plus 4.5 software. The cells present in the projected image were counted and the resulting average counts were expressed as cells per $\mathrm{mm}^{2}$. The possible differences between treatments (groups) for each gland and each monoclonal antibody used were determined by the Kruskal-Wallis test, followed by the Mann-Whitney test. The difference was considered significant with $\mathrm{p}<0.05$.

\section{RESULTS}

The results of the histopathology and bacteriology studies are shown in Table 2. At the moment of slaughter, only the challenge bacterium could be re-isolated in the IE group in 3 of 4 sheep from the epididymal tail, in 3 of 4 sheep from the ampullae, and in 1 of 4 sheep from the seminal vesicle, the prostate and the bulbourethral gland. Inflammatory lymphoplasmocytary infiltrates, with different intensity degrees, occurred in the ampullae and seminal vesicles, and were concurrent with the

Table 2. Histopathology and bacteriology of the reproductive tract organs

\begin{tabular}{lccccc}
\hline Group & Number & Ampulla & $\begin{array}{c}\text { Seminal } \\
\text { vesicle }\end{array}$ & $\begin{array}{c}\text { Disseminated } \\
\text { prostate }\end{array}$ & Bulbourethral \\
\hline \multirow{2}{*}{ IU } & 1 & NC & LI+ & NC & NC \\
& 2 & NC & NC & NC & NC \\
& 3 & LI+ & LI+ & NC & NC \\
& 4 & LI+ & NC & NC & NC \\
IE & 5 & LI++ A.s & LI+++ & LI+ & NC \\
& 6 & LI+ & LI+++ & LI+ & NC \\
& 7 & LI++ A.s & LI +A.s & LI +A.s & NC A.s \\
& 8 & LI++ A.s & LI+ & NC & NC \\
CON & 9 & NC & NC & NC & NC \\
& 10 & NC & NC & NC & NC \\
& 11 & NC & NC & NC & NC \\
& 12 & NC & LI+ & NC & NC
\end{tabular}

$\overline{\mathrm{IE}}=$ intraepididymal, $\mathrm{IU}=$ intraurethral, $\mathrm{CON}=$ control. A.s. = Actinoba cillus seminis isolation at slaughter, 35 days post-inoculation. Histopathology: $\mathrm{NC}=$ no changes, $\mathrm{LI}=$ presence of lymphoplasmocytary infiltrate (+scarce, ++ abundant, +++very abundant). 
Table 3. CD4, CD8, CD45R0, WC1, CD14 AND CD1b cells per $\left(\mathrm{mm}^{2}\right)$ in the accessory sex glands of rams inoculated with Actinobacillus seminis

\begin{tabular}{|c|c|c|c|c|c|c|c|}
\hline Gland & Group & $\mathrm{CD} 4$ & CD8 & CD45RO & WC1 & CD14 & CD1b \\
\hline \multirow[t]{3}{*}{ Seminal Vesicle } & IU & $78.0 \pm 60.2^{\mathrm{b}}$ & $93,0 \pm 75.7^{\mathrm{b}}$ & $274.3 \pm 125.5^{\mathrm{b}, \mathrm{e}}$ & $19.4 \pm 7.1^{\mathrm{a}, \mathrm{b}}$ & $52,7 \pm 27.7^{b}$ & $0.0 \pm 0.0$ \\
\hline & IE & $334.7 \pm 144.2^{\mathrm{a}}$ & $316.6 \pm 24.6^{a}$ & $864.6 \pm 466.2^{\mathrm{a}}$ & $75.0 \pm 43.7^{\mathrm{a}}$ & $142.7 \pm 37.1^{\mathrm{e}}$ & $2.8 \pm 5.6$ \\
\hline & $\mathrm{CON}$ & $11.1 \pm 22.3$ & $38.9 \pm 31.1$ & $67.9 \pm 39.7$ & $1.4 \pm 2.8$ & $41,6 \pm 13.2$ & $0.0 \pm 0.0$ \\
\hline \multirow[t]{3}{*}{ Ampulla } & IU & $124.1 \pm 173.1^{\mathrm{e}}$ & $180.4 \pm 132.0^{\mathrm{a}}$ & $222.0 \pm 178.9^{\mathrm{e}}$ & $31.9 \pm 25.4^{\mathrm{a}}$ & $166.5 \pm 59.9^{a}$ & $0.0 \pm 0.0$ \\
\hline & IE & $76.3 \pm 18.9^{\mathrm{a}}$ & $205.4 \pm 141.3^{\mathrm{a}}$ & $295.2 \pm 73.0^{\mathrm{a}}$ & $33.3 \pm 19.8^{a}$ & $263.4 \pm 129.4^{\mathrm{a}}$ & $5.5 \pm 6.4$ \\
\hline & $\mathrm{CON}$ & $16.7 \pm 4.5$ & $33.3 \pm 15.7$ & $40.3 \pm 15.9$ & $1.4 \pm 2.8$ & $33.3 \pm 19.5$ & $0.0 \pm 0.0$ \\
\hline \multirow[t]{3}{*}{ Disseminated Prostate } & IU & $52.7 \pm 28.2^{\mathrm{e}}$ & $41.5 \pm 34.7$ & $140.3 \pm 121.8$ & $0.0 \pm 0.0$ & $86.1 \pm 35.3$ & $0.0 \pm 0.0$ \\
\hline & IE & $13.9 \pm 11.5^{\mathrm{f}}$ & $30.5 \pm 14.7$ & $51.4 \pm 38.9$ & $1.4 \pm 3.2$ & $97.2 \pm 29.4$ & $0.0 \pm 0.0$ \\
\hline & $\mathrm{CON}$ & $14.8 \pm 11.5$ & $7.4 \pm 8.5$ & $27.8 \pm 11.1$ & $3.7 \pm 6.4$ & $42.6 \pm 36.1$ & $0.0 \pm 0.0$ \\
\hline \multirow[t]{3}{*}{ Bulbourethral Gland } & IU & $23.6 \pm 15.9^{e}$ & $19.5 \pm 19.2$ & $8.3 \pm 5.5 \mathrm{~b}$ & $0.0 \pm 0.0$ & $22.2 \pm 12.0$ & $0.0 \pm 0.0$ \\
\hline & IE & $12.5 \pm 5.3$ & $18.0 \pm 18.3$ & $36.0 \pm 45.3^{\mathrm{a}}$ & $5.5 \pm 0.0$ & $27.8 \pm 23.5$ & $0.0 \pm 0.0$ \\
\hline & $\mathrm{CON}$ & $9.7 \pm 11.5$ & $11.1 \pm 18.7$ & $4.2 \pm 8.4$ & $0,0 \pm 0.0$ & $2.8 \pm 3.2$ & $0.0 \pm 0.0$ \\
\hline
\end{tabular}

$\mathrm{IE}=$ intraepididymal, $\mathrm{IU}=$ intraurethral, $\mathrm{CON}=$ control. ${ }^{\text {a }}$ Significance compared with the CON group $\mathrm{p}<0.05,{ }^{\mathrm{b}}$ significance compared with the IE group $\mathrm{p}<0.05,{ }^{\mathrm{e}}$ compared with the CON group $\mathrm{p}<0.1,{ }^{\mathrm{f}}$ compared with the IU group $\mathrm{p}<0.1$. Median \pm SD.

\section{Seminal vesicle}
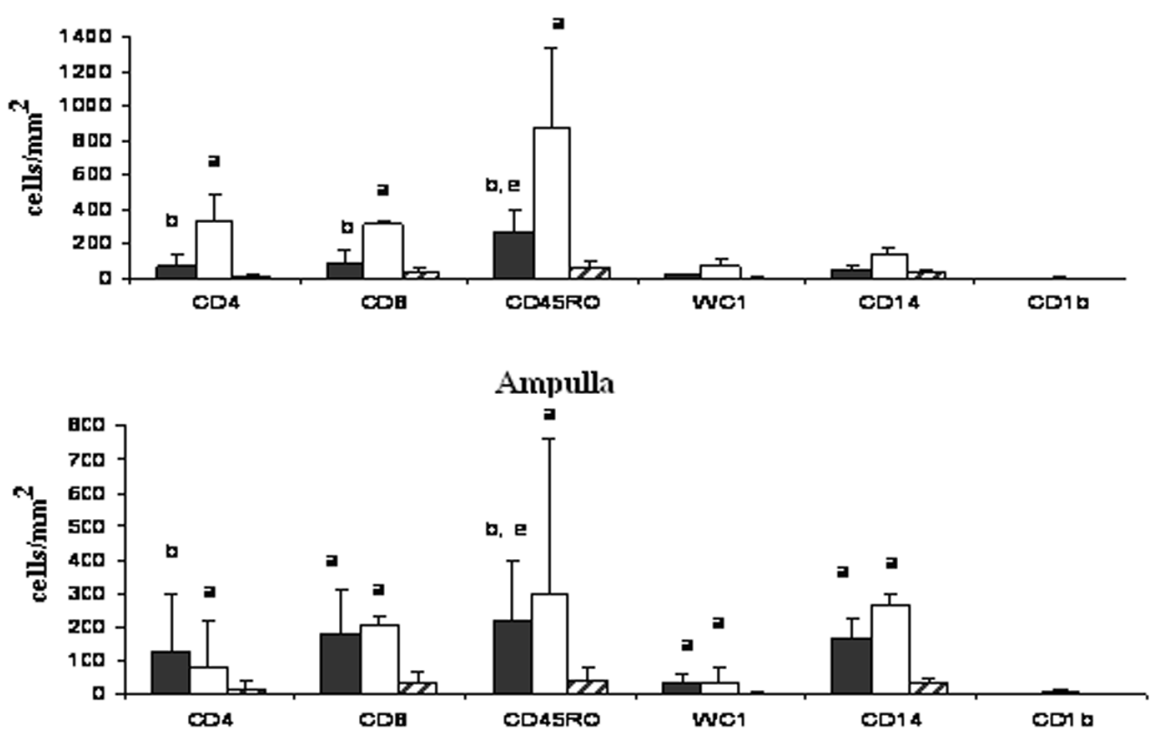

Disseminate prostate

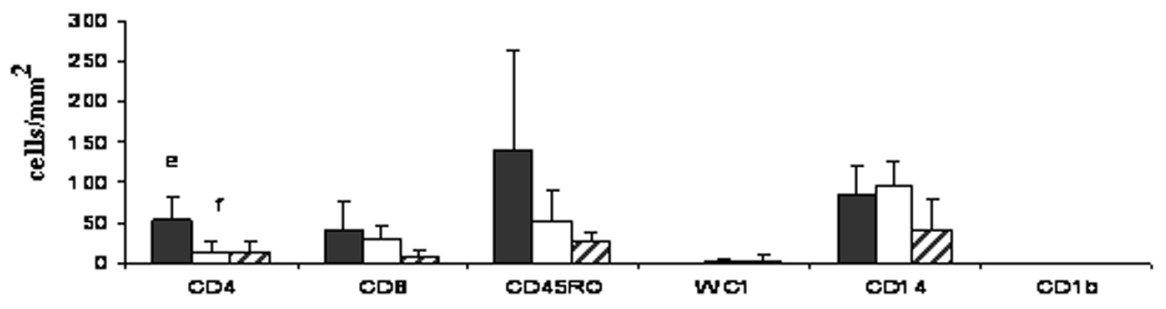

Bulbourethual gland

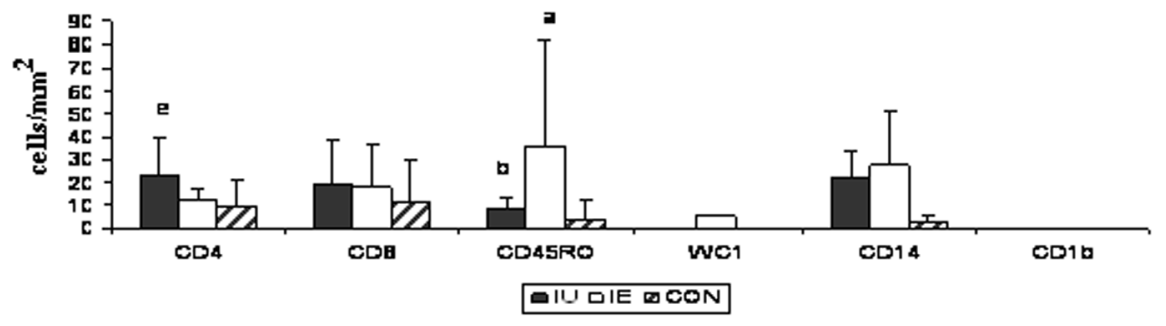

Fig.1. Number of CD4, CD8, WC1, CD45R0, CD14 and CD1b lymphocytes per $\mathrm{mm}^{2}$ in the accessory sex glands of rams inoculated with $A$. seminis. IU Intraurethral group, IE Intraepididymal group, CON Control group. a significance compared with the CON group $\mathrm{p}<0.05$, $\mathrm{b}$ significance compared with the IE group $\mathrm{p}<0.05$, e compared in the CON group $\mathrm{p}<0.1, \mathrm{f}$ compared in the IU group $\mathrm{p}<0.1$. 
Actinobacillus seminis isolate in 3:4 animals in the IE group.

The average counts obtained for the evaluated cells in each group are summarized in Table 3 and Figure 1. A greater overall cellularity can be observed in the seminal vesicles and the ampullae from the IU and IE groups, compared with the control group. The most important differences occurred in the ampullae and the seminal vesicles from the animals with concurrent isolation of $A$. seminis from these structures.

In the ampullae of the deferent duct in the IE group, there were differences from the CON group in CD4 ( $p=0.003)$, CD8 ( $p=0.028), C D 45 R 0(p=0.005), W C 1(P=0.007)$ and CD14 ( $p=0.028)$ counts, but no differences were noted in CD1b, although the presence of labeled cells was demonstrated $\left(5.5 \pm 6.4 \mathrm{~mm}^{2}\right)$. Differences were also found between the IU and CON groups in CD8 $(p=0.028)$, WC1 $(p=0.002)$ and CD14 ( $p=0.003)$, with a trend in CD45RO ( $p=0.083)$. No significant differences were found between cell populations from the ampullae in the IU and IE groups.

In the seminal vesicles, differences were present between the IE and CON groups in CD4, CD8, WC1 and CD45RO $(p=0.029)$, as well as a tendency in CD14 $(p=0.057)$; these
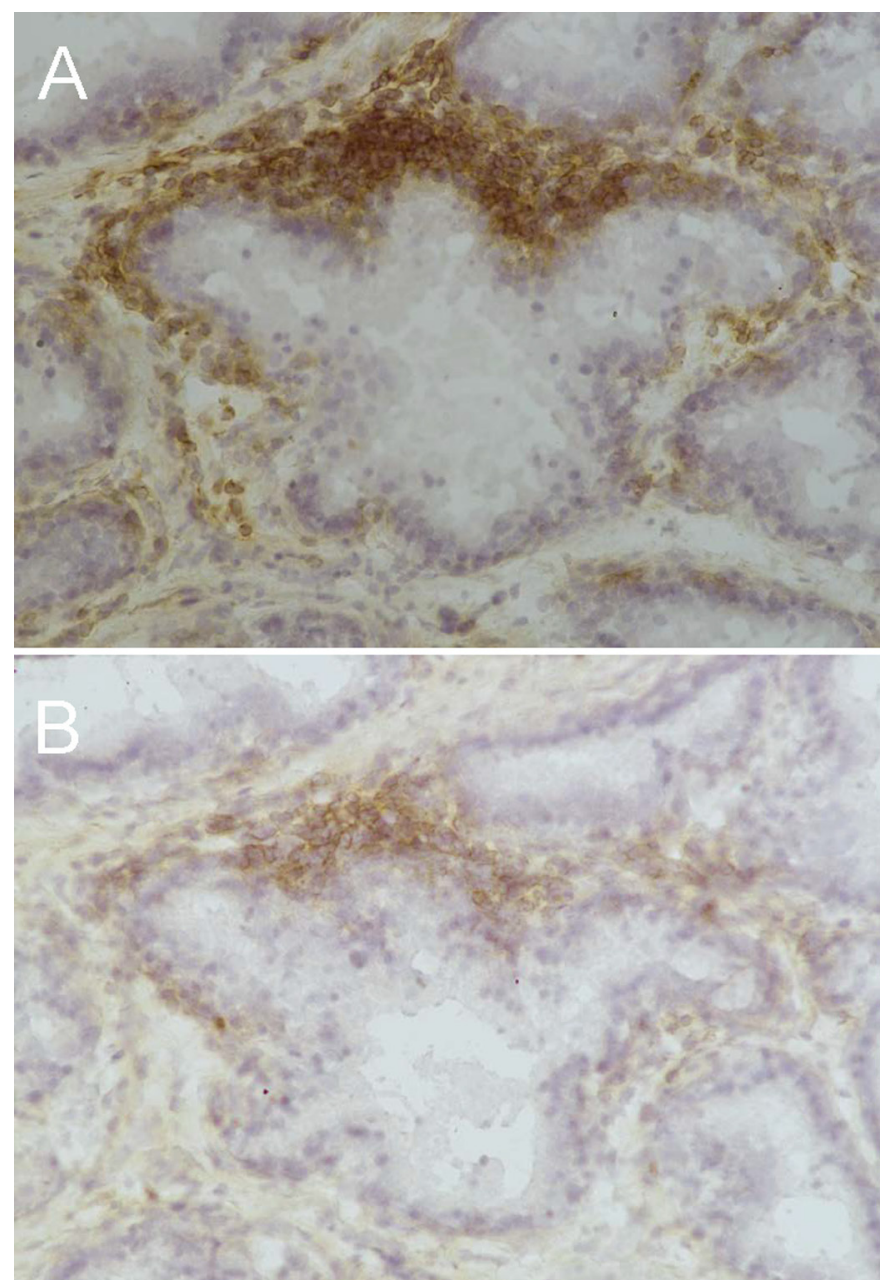

Fig.2. Lymphoid infiltration by an acinus in the seminal vesicle. Serial sections of seminal vesicle: a) Marking to CD8 (ocher) lymphocytes. IP, obj.20x, b) Marking for CD4 (ocher) lymphocytes. IP, obj.20x.

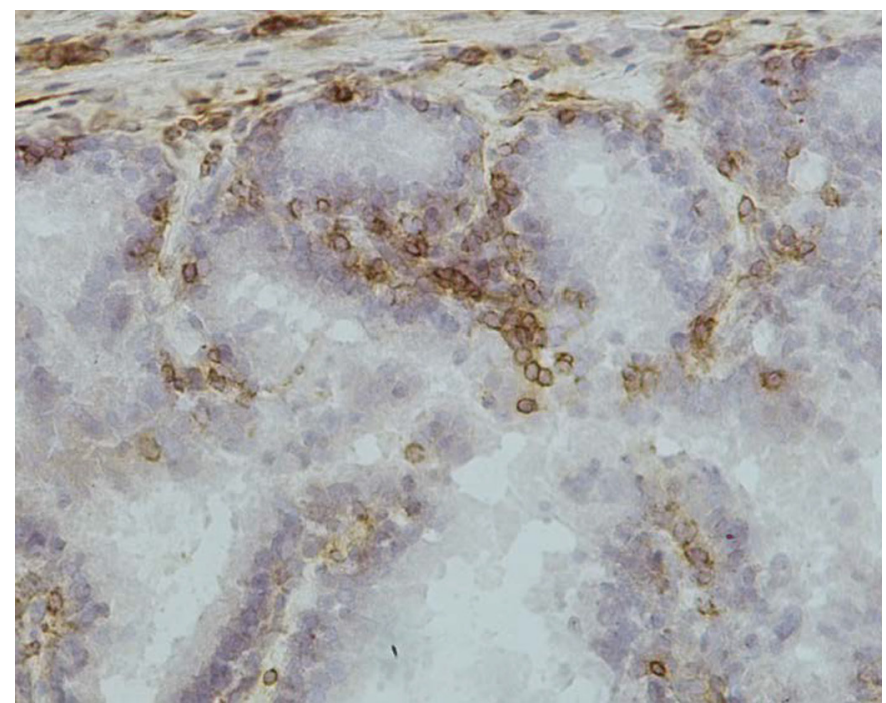

Fig.3. CD45R0 by an acinus in the seminal vesicle. CD45RO lymphocytes infiltrating the stroma and acinar epithelium. IP, obj. 20x.

differences were also maintained between the IE and IU treatments, and were even significant for CD14 ( $\mathrm{p}=0.029)$. There was a significant difference in the vesicle counts in WC1 between the CON and IU groups $(p=0.029)$, with a tendency in CD45RO ( $p=0.057)$. A scarce number of CD1b $\left(2.8 \pm 5.6 \mathrm{~mm}^{2}\right)$ was found in the IE group.

No differences were found in the disseminated prostate; a trend was demonstrated only for CD4 between IU, CON and IU, IE ( $\mathrm{p}=0.057)$.

In the bulbourethral glands, differences were demonstrated between the IE and CON groups, and between the IE and IU groups in WC1 $(p=0.006$ and $p=0.029$, respectively) and in CD14 cells between the IU and CON groups $(\mathrm{p}=0.042)$.

In the seminal vesicles, lymphoid accumulations were found in the periphery of the acini with presence of CD8 and CD4. CD4 lymphocytes were frequently present in the conjunctival stroma of the glands, and CD8 were present with a closer relationship with the basal membrane of acini (Fig.2). CD45RO were present in both positions and were frequently located within the acini (Fig.3). CD14 labeling occurred in the stroma, on the macrophages and in the endothelia.

Regarding immunoglobulin-containing cells (IgCC), the most frequent labeling in the accessory sex glands corresponded to IgA, followed by IgM and IgG. In the CON group, the bulbourethral gland and the disseminated prostate presented IgA- and IgM-containing cells, which were not seen in the ampullae and the vesicle (Table 4, Fig.4)

IgG-containing cells were seen in the IE and IU groups, in a greater proportion in the seminal vesicle and in the deferent duct ampullae. Coincidently, it was from these glands that $A$. seminis isolates were obtained more frequently. Statistical differences were found in the ampullae for IgMand IgG- containing cells between the CON and IE groups $(p=0.029)$, and between the IE and IU groups $(p=0.029)$.

Significant differences were found between IgA-containing cells ( $p=0.029)$ in the bulbourethral glands in the CON and IE groups, while IgM-containing cells showed a trend 
$(\mathrm{p}=0.059)$.

Trends were present in the vesicles in the Kruskal Wallis test $(p<0.1)$, but the great variability in the cell counts from these samples prevents these differences from being evident between the groups (data not shown).

IgG- containing cells were only seen in the IU and IE groups, mainly in the latter, with percentages of 11,9 and 2 $\%$ in the ampulla, the seminal vesicle and the bulbourethral gland, respectively. Conversely, no IgG labeling was seen in the CON group in any gland.

The greater cellularity observed in the bulbourethral glands and the disseminated prostate stands out in all groups, mainly due to the presence of IgA- and IgM- containing cells (Figure 5). In the bulbourethral gland, IgA- containing cells ranged between 73 and $79 \%$, and IgM- containing cells ranged between 21 and 25\%, while in the disseminated prostate, 82 to $90 \%$ were IgA- containing cells and between 10 and $18 \%$ were IgM- containing cells, and the

\section{Seminal vescicle}
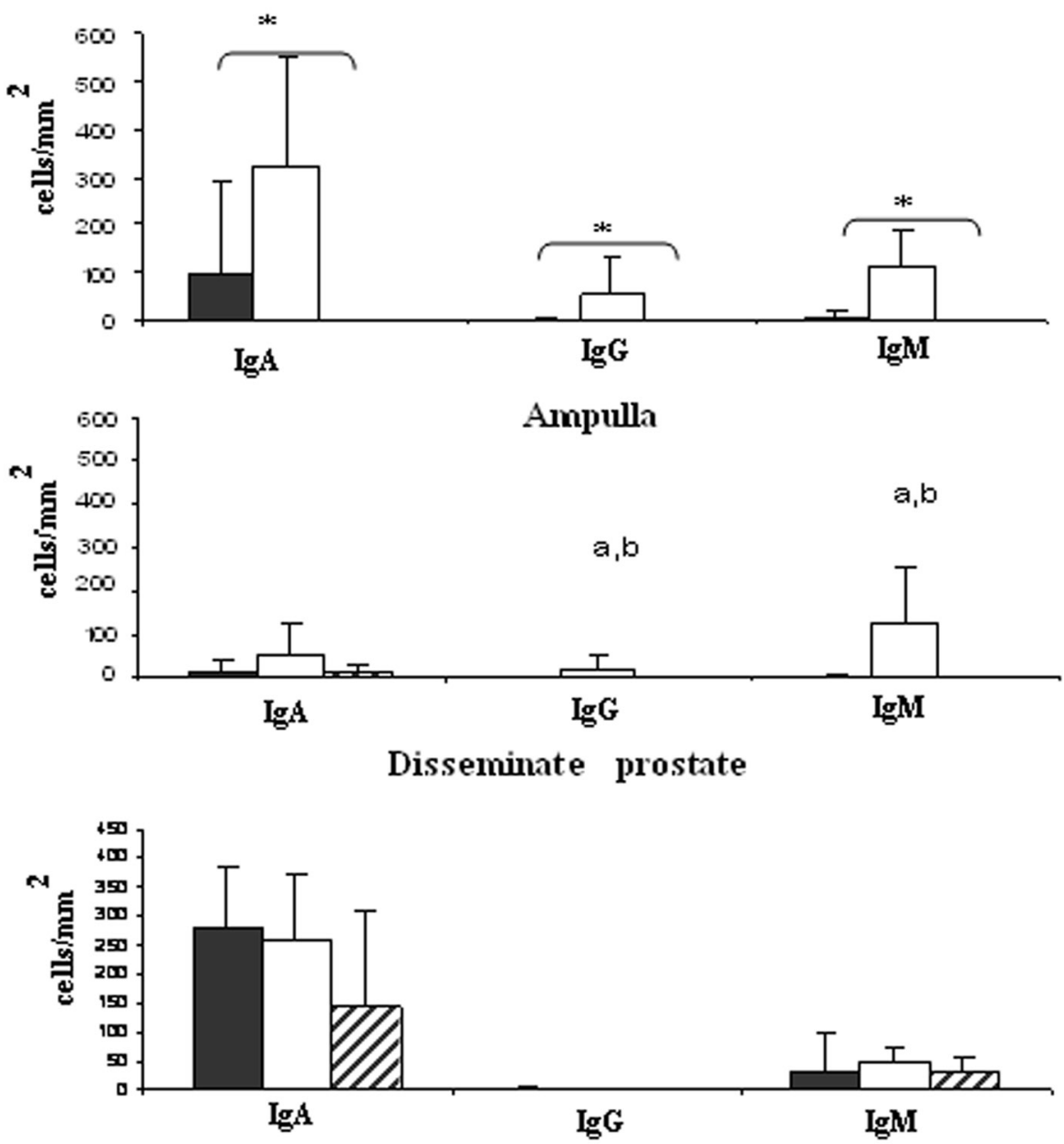

Bulbourethual gland

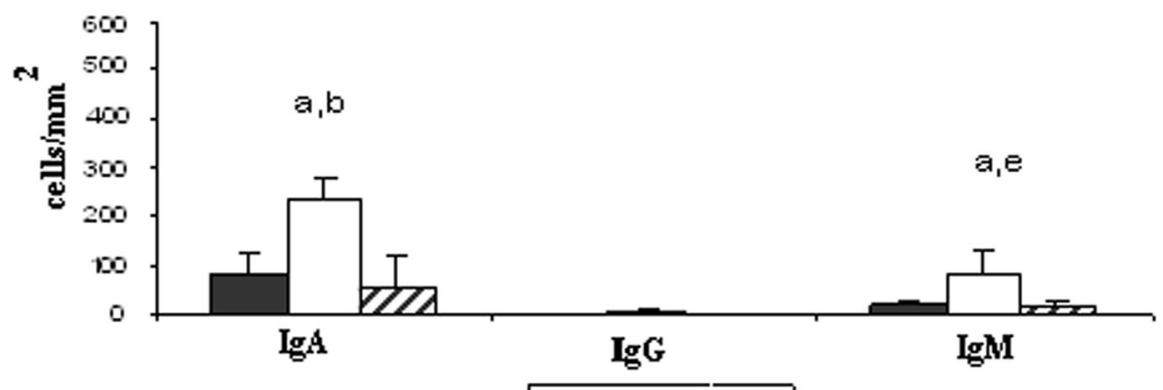

IU IE IOCON

Fig.4. Number of IgA-, IgG- and IgM-containing cells in the accessory sex glands of rams inoculated with A. seminis. IE intraepididymal, IU intraurethral, CON control. a significance compared with the CON group $p<0.05$; b significance compared with the IU group $p<0.05$; e compared in the IU group $\mathrm{p}<0.1 ;$ difference in organ $\mathrm{p}<0.1$ (Kruskal Wallis test) very heterogeneous reactions within the group. 
Table 4. IgA-, IgG- and IgM-containing cells in the accessory sex glands per ( $\left.\mathrm{mm}^{2}\right)$

\begin{tabular}{lcccc}
\hline Gland & Group & IgA-containing cells & IgG-containing cells & IgM-containing cells \\
\hline Seminal Vesicle & IU & $97.4 \pm 194.9^{*}$ & $1.4 \pm 2.8^{*}$ & $7.0 \pm 14.0^{*}$ \\
& IE & $319.9 \pm 233.9^{*}$ & $52.8 \pm 78.5^{*}$ & $110.6 \pm 75.2^{*}$ \\
\multirow{5}{*}{ Ampulla } & CON & $0.0 \pm 0.0^{*}$ & $0.0 \pm 0.0^{*}$ & $0.0 \pm 0.0^{*}$ \\
& IU & $12.4 \pm 24.9$ & $0.0 \pm 0.0$ & $1.4 \pm 2.8$ \\
Disseminated Prostate & $49.1 \pm 76.4$ & $16.7 \pm 15.8^{\mathrm{a}, \mathrm{b}}$ & $123.5 \pm 128.1^{\mathrm{a}, \mathrm{b}}$ \\
& IE & $11.2 \pm 15.9$ & $0.0 \pm 0.0$ & $0.0 \pm 0.0$ \\
CON & $280.3 \pm 106.1$ & $1.4 \pm 2.8$ & $32.5 \pm 64.9$ \\
Bulbourethral & IE & $243.7 \pm 94.9$ & $0.0 \pm 0.0$ & $48.1 \pm 21.4$ \\
& CON & $143.6 \pm 167.2$ & $0.0 \pm 0.0$ & $31.8 \pm 25.3$ \\
& IU & $84.5 \pm 44.8$ & $0.0 \pm 0.0$ & $22.2 \pm 7.8$ \\
& IE & $237.4 \pm 40.6{ }^{\mathrm{a}, \mathrm{b}}$ & $5.5 \pm 6.4$ & $81.2 \pm 53.1$ a,e
\end{tabular}

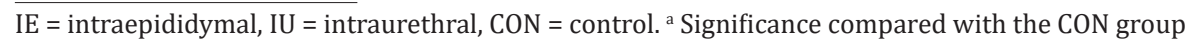
$\mathrm{p}<0.05$, $^{\mathrm{b}}$ significance compared with the IU group $\mathrm{p}<0.05$, e significance compared with the IU group $\mathrm{p}<0.1,{ }^{*} \mathrm{p}<0.1$ (Kruskal Wallis test) very heterogeneous reactions within the group.
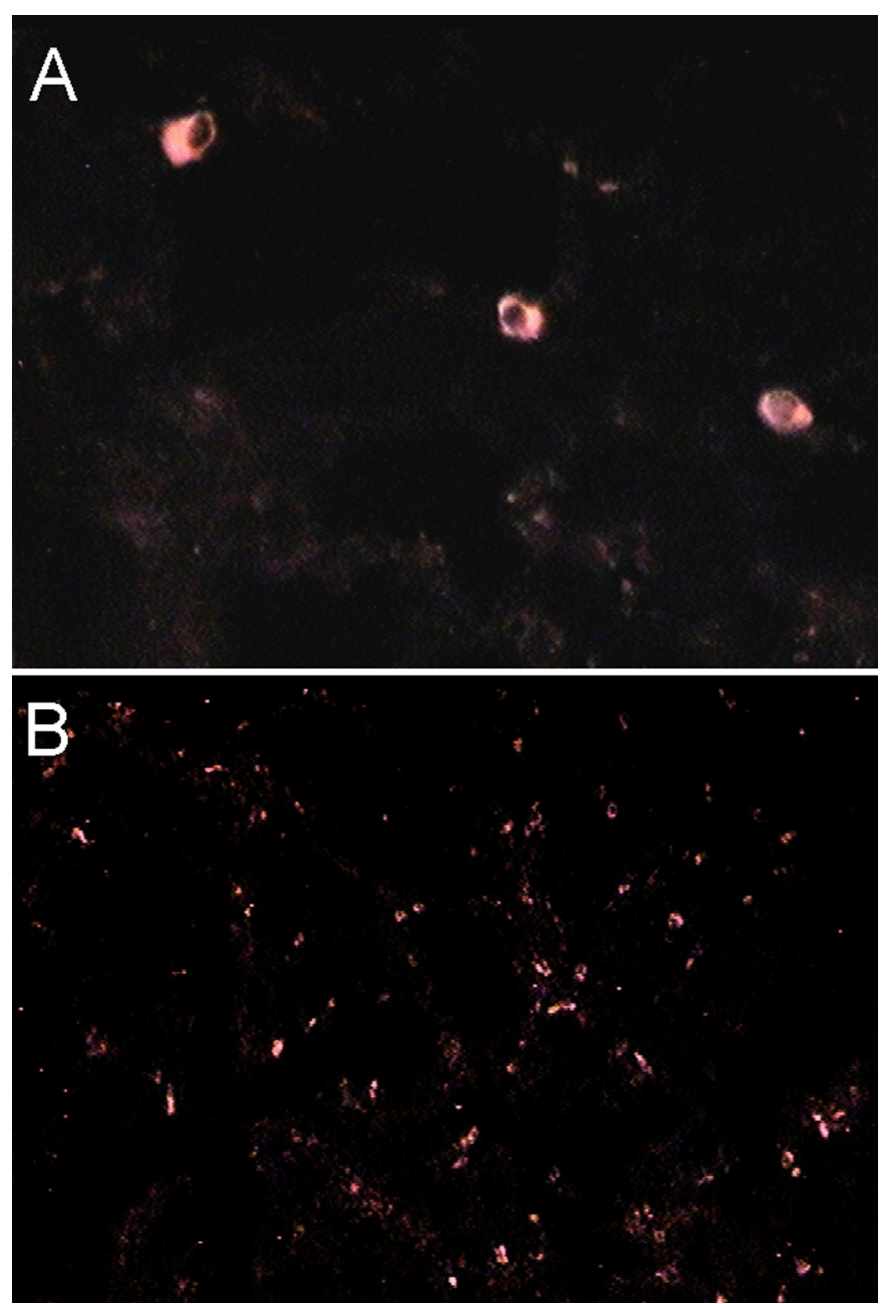

Fig.5. IgA and IgM positive cells in the in the accessory sex glands of the reproductive system. A) IgM positive plasma cells present in disseminated prostate. IF, obj. 40x. B) Appearance of the bulbourethral gland with abundant IgA positive cells, located in the interstitial tissue. IF, obj. 10x.

positive IgG- containing cells counts were almost null.

The histological location of IgCC also showed differences between the glands studied. In the disseminated prostate and the bulbourethral gland, IgA- and IgM- containing cells were observed mainly in the scarce connective tissue surrounding the acini. A clearly positive IgA labeling was observed in the inside of some acini in association with glandular secretion. IgG- containing cells from the seminal vesicles were located in the connective tissue that separates the glandular lobules, while IgA- containing cells were observed in the acini.

\section{DISCUSSION}

In this experiment, several facts are confirmed that may contribute to demonstrating the different susceptibility of the accessory glands to Actiobacillus seminis infection (Al-Katib \& Dennis 2005, Acosta-Dibarrat et al. 2006). As previously mentioned regarding $A$. seminis, the bacterium was isolated more frequently from the ampullae and seminal vesicles, suggesting that, in these structures, bacterial establishment and permanence is somehow facilitated, although these were the glands that showed the most notable inflammatory changes behind the epididymides, which were directly inoculated. In the vesicles and ampullae of the CON group, no positive IgA-, IgM- or IgG-containing cells were found, or they were found in a lower number than in the inoculated groups, a condition that may facilitate bacterial establishment. This finding differentiates the seminal vesicles and the ampullae from the bulbourethral gland and the disseminated prostate, which, conversely, demonstrated an important number of these cells in the aforementioned group.

The distribution of IgCC in control and infected sheep glands observed in this work is consistent with the findings demonstrated in bulls, where IgCC are also not found or are present in a very limited number in the seminal vesicles of normal animals (Campero et al. 1989, 1990), while in the presence of an inflammatory response in the genital tract, IgCC appear in the ampullae and the seminal vesicles (Campero et al. 1989). It has been noted that the production of IgA and IgG in the seminal vesicles in the bull is an essential component of the local immune response (Bier et al. 1977). However, in other studies, no IgCC are found, or these are found in a very limited number in the seminal vesicles of normal bulls; therefore, it is unlikely that this is the origin of the immunoglobulins present in the semen (Campero et 


\section{al. 1989, 1990).}

Foster et al. (1988), using 5 one-year-old sheep and 12 sheep older than 4 years, reported the presence of IgA- and IgG-containing cells, mainly in the bulbourethral gland and the prostate, and only occasionally in the seminal vesicles and the ampullae; these results are consistent with the results of this work. However, in contrast with the results of this work, these authors found high percentages of IgG-containing-cells, a condition that only occurred in a small number in the IE group in the seminal vesicles and ampullae with active inflammatory processes. This difference may be attributed to the fact that the animals used by Foster et al. (1988), had subclinical alterations of the reproductive system with local infection, since no bacteriological examinations of the semen were carried out and they only verified that the animals were free of $B$. ovis by serology; they also do not distinguish between young animals and adult animals, and variations are likely to occur in the amount and distribution of IgCC due to age, as has been reported in bulls (Campero et al. 1989).

In humans, positive IgA- and IgM-containing cells are described in the prostate, the bulbourethral gland and the penile urethra, where only a limited number of IgG-containing cells are found. However, little is known about the immunobiology of seminal vesicles, where no plasma cells are seen, but an occasional expression of pIgR is found (Anderson \& Pundey 1999).

The information available on the presence and distribution of the cell types studied in the male reproductive apparatus, especially in the accessory sex glands, is limited. In this study, no differences were found in the distribution of CD4, CD8, WC1 and macrophages in the disseminated prostate, the bulbourethral gland, the seminal vesicle and the ampulla of the deferent duct in sheep of the CON group, in contrast to the observations for IgCC. The disseminated prostate is closely related to the prostatic urethra and its submucosa, strongly infiltrated by CD4 and CD8 lymphocytes and macrophages, a condition that may favor antigenic recognition and presentation and may promote the proliferation and differentiation of B lymphocytes at this zone. In the case of bulbourethral glands, this relationship is not clear, therefore, it may be possible that this gland behaves as an effector site for the immune response, to which cells activated in other parts of the reproductive apparatus or other organs may arrive (Russell \& Mestecky 2002). There is no information available on the presence of endothelial VCAM-1, ICAM-1 or MAdCAM-1 receptors in the bulbourethral glands.

A. seminis triggered an inflammatory response in the accessory glands, mainly in the seminal vesicles and the ampullae, with a significant increase in CD8, CD4, TCR $\gamma \delta$ and CD14 lymphocytes and CD45RO cells in both the IU and IE groups at 35 days post-inoculation, although in the IU group no A. seminis isolations were achieved, and only two animals demonstrated a serologic response (Acosta-Dibarrat et al. 2007). These facts suggest an immune response for controlling the establishment and development of the infection induced by the inoculation of the bacterium by IU route, which is considered as the route that more closely resembles the natural acquisition of $A$. seminis infection (Jansen 1980, 1983). In the case of IE-challenged animals, the damage caused to the epididymis and the constant presence of bacteria at this site may have prevented the local response of the ampullae and vesicles from eradicating the infection. These facts support the possibility that $A$. seminis behaves as an opportunistic bacterium, that is only capable of causing disease in the presence of predisposing factors (Jansen 1983, Walker \& Leamaster 1986).

No conclusions can be drawn from this experiment regarding the type of response induced by the experimental infection with A. seminis. However, in the inflammatory foci of both the vesicles and the ampullae, there was a significant increase of labeled cells for TCR $\gamma / \delta$ (WC1), CD 4 and CD8 lymphocytes, macrophages, and even dendritic cells, particularly in IE animals. The changes in IgCC in these same glands suggest an interaction of type Th1 and Th2 responses in the response to the bacterium and its potential eradication, considering the results for the IU group. It has been reported that lymphocytes from the spleen of mice previously inoculated with $A$. seminis and challenged in vitro with the whole bacterium, produced IL4, IL-2 and IFN- $\gamma$, suggesting that $A$. seminis induces both responses (Patlani et al. 2006). The changes observed in cell populations in this work may have been influenced by the development of autoimmune responses (Paolicchi et al. 2000), particularly in the case of IE inoculated animals. However, controls intraepididymally inoculated with SSF demonstrated a reduced number of immune response cells compared to treated animals.

A certain proportion of TCR $\gamma \delta$ lymphocytes express the WC1 marker on their surface. These cells are abundant in the peripheral blood and jejunal mucosa of ruminants, especially in young animals, and may provide an immediate mechanism of Th1 cytokine production (Pollock and Welsh, 2002, McClure 2009). The increase in WC1 in the seminal vesicles and ampullae was significant relative to the CON group, but its absolute number was lower than that of CD4 and CD8 lymphocytes. The increase in TCR $\gamma \delta$ lymphocytes has been reported in various inflammatory or infectious diseases (Baldwin et al. 2000). These cells produce keratinocyte growth factor, and may be implicated in epithelial repairing processes (Van der Broek et al. 2005).

The common leukocytic antigen CD45 is a modulator of T-lymphocyte activation signal transduction; the CD45RO isoform is present in memory CD4 and CD8 T-lymphocyte subclasses (Bembridge et al., 1993). This isoform is also expressed in monocytes, granulocytes and mononuclear cells presenting WC1, TCR $\gamma \delta, C D 4$ and CD8, but is not expressed by B lymphocytes (Bembridge et al. 1995). This isoform is particularly abundant in mucosa-resident lymphocytes, especially in the intestinal lamina propria, where it may represent $93 \%$, in contrast with $30 \%$ in peripheral blood (Stephen \& Hiroshi 1999). Its increase in the vesicle and ampulla of the infected animals appears to be an additional indicator of immune response induction by the presence of the bacterium.

The CD1b marker is a surface glycoprotein present in 
dendritic cells, through which it is capable of presenting lipid and glycolipid antigens to T cells (Porcelli et al. 1998, Rhind 2001, McClure 2009). Positive cells are considered excellent antigen presenters for TCR $\gamma \delta$ lymphocytes, and are the main cells responsible for the production of an effective response against these intracellular pathogens (Rhind 2001). In this work, only a limited number of positive cells were present in the ampullae and the seminal vesicles, mainly in the IE group, where they appeared concurrently with a significant increase in TCR $\gamma \delta$ lymphocytes, suggesting that dendritic cells would not be relevant in the antigenic presentation in the accessory sex glands of rams. In contrast, macrophage increase in the ampulla and the vesicle in the IU and IE groups would facilitate antigen presentation in the glands in A. seminis infection. CD14, that has been reported to be capable of recognizing LPS present in Gram- bacteria, is found in the macrophages' surface, alone or associated with proteins (Wright et al. 1990). The observation of endothelial labeling with CD14 in the ampullae and seminal vesicles with inflammatory processes may be explained, considering that the LPS of Gram-negative bacteria has been reported to stimulate the expression of this marker in the endothelia, with TNF- $\alpha$ and IL-6 production (Dai et al. 2002).

\section{CONCLUSIONS}

Inoculation with Actinobacillus seminis caused pathologic alterations, not only at the site of inoculation in the epididymal tails, but also in the accessory glands of the male reproductive system, mainly in the ampullae of the deferent duct and the seminal vesicles.

Differences could be found in the distribution and number of IgCC among glands in the CON group. The ampullae and vesicles from this group presented a limited number of cells or no cells at all, while these were abundant in the bulbourethral gland and the prostate, mainly of the IgA- and IgM- containing cells. In IU- and IE-treated groups, positive IgG-containing cells were present in those organs with a marked inflammatory response, in the ampullae and vesicles and in the inoculated epididymal tails.

The CD4/CD8 ratio did not show a predominance of any of these subtypes in the tissues where A. seminis was isolated.

CD1b dendritic cells were scarce in the accessory glands of the reproductive system, where the antigenic presentation functions in A. seminis infection seem to be performed by CD14 macrophages.

The immunobiology of the accessory glands may be the reason why there are differences in their susceptibility to A. seminis infection, and why they eventually act as a site (refuge) of bacterial permanence.

Acknowledgments.- This research was supported by PAPITT-UNAM, IN206101 and PROMEP/103.5/12/9805. We are grateful to Márcia Monks Jantzen of the Department of Veterinary Preventive Medicine, Federal University of Rio Grande do Sul for the translation of the abstract to the Portuguese.

Conflict of interest stamen. The authors have no competing interest.

\section{REFERENCES}

Acosta-Dibarrat J., Buendía-J.A., Soriano-Vargas E., Oca-Jiménez R.M. \& Tórtora-Pérez J. 2014. Distribuição de células da resposta imune na uretra pélvica e em prepúcio de carneiros. Pesq. Vet. Bras. 34:270-276

Acosta-Dibarrat J., Díaz-Aparicio E., Arellano-Reynoso B., Tenorio-Gutiérrez V. \& Tórtora-Pérez J. 2006. Experimental induction of epididymitis in sheep, by intra-urethral inoculation of Actinobacillus seminis: a bacteriological, serological and histopathological study. Téc. Pecu. Méx. 44:257-267.

Acosta-Dibarrat J., Díaz-Aparicio E., Tenorio-Gutiérrez V.R., Suárez-Güemes F. \& Tórtora-Pérez J. 2007. Determination of Pathological Changes in the Reproductive Tract, IgG, IgM and IgA Antibodies in Blood, Seminal Plasma and Smegma of Rams Inoculated with Actinobacillus seminis. J. Anim. Vet. Adv. 6:105-113.

Al-Katib W.A. \& Dennis S.M. 2005. Experimental transmission of Actinobacillus seminis infection to rams. Vet. Rec. 157:143-147.

Anderson D.J. \& Pudney J. 1999. Human Male Genital Tract Immunity and Experimental Models, p.1411-1422. In: Ogra P.L., Mestecky J., Lamm M.E., Strober W., Bienenstock J. \& McGhee J.R. (Eds), Mucosal Immunology. 2nd ed. Academic Press, San Diego.

Bagshaw P.A. \& Ladds P.W. 1974. A study of the accessory sex glands of bulls in abattoirs in Northern Australia. Aust. Vet. J. 50:489-495.

Baldwin C.L., Sathiyaseelan T., Rocchi M. \& McKeever M. 2000. Rapid changes occur in the percentage of circulating bovine WC1+ $\gamma \delta \mathrm{Th} 1$ cells. Res. Vet. Sci. 69:176-180.

Bembridge G.P., McHugh N.D., McKeever D., Awino E., Sopp P., Collins R.A., Gelder K.I. \& Howard C.J. 1995. CD45RO expression on bovine T cells: relation to biological function. Immunology 86:537-544.

Bembridge G.P., Parsons K.R., Sopp P., Mac Hugh N.D. \& Howard C.J. 1993. Comparison of monoclonal antibodies with potential specificity for restricted isoforms of the leukocyte common antigen (CD45R). Vet. Immunol. Immunopathol. 39:129-136.

Bier P.J., Hall C.E., Duncan J.R. \& Winter A.J. 1977. Measurement of immunoglobulins in reproductive tract fluids of bulls. Vet. Microbiol. 2:1-11.

Burgess G.W. 1982. Ovine contagious epididymitis: a review. Vet. Microbiol. 7:551-575.

Campero C.M., Ladds P.W., Hoffmann D. \& De'ath G. 1989. Immunoglobulin containing cells in normal and inflamed accessory sex glands of bull. Aust. Vet. J. 66:137-140.

Campero C.M., Ladds P.W., Hoffmann D., Duffield B., Watson D. \& Fordyce G. 1990. Immunopathology of experimental Brucella abortus strain 19 infection of the genitalia of bulls. Vet. Immunol. Immunopathol. 24:235-246.

Cavalieri J. \& Van Camp S.D. 1997. Bovine seminal vesiculitis. A review and update. Vet. Clin. North Am. Food Anim. Pract. 1:233-241.

Dai L., Gong J., Luo Y. \& Liu C. 2002. Expression of CD (14) protein in liver sinusoidal endothelial cells during endotoxemia. Zhonghua Gan Zang Bing Za Zhi.10:93-95.

Foster R.A., Ladds P.W., Briggs G.D. \& Hoffmann D. 1987. Pathology of the accessory sex glands of rams infected with Brucella ovis. Aust. Vet. J. 64:248-250.

Foster R.A., Ladds P.W., Hoffmann D. \& Husband A.J. 1998. Immunoglobulins and immunoglobulin-containing cells in the reproductive tract of normal rams. Aust. Vet. J. 65:16-20.

Furuya R., Takahashi S., Furuya S., Kunishima Y., Takeyama K. \& Tsukamoto T. 2004. Is seminal vesiculitis a discrete disease entity?. Clinical and microbiological study of seminal vesiculitis in patients with acute epididymitis. J. Urol. 171:1550-1153.

Healey M.C., Hwang H.H., Elsner Y.Y. \& Johnston A.V. 1991. A model for demonstrating the adhesion of Actinobacillus seminis to epithelial cells. Can. J. Vet. Res. 55:121-127.

Jansen B.C. 1980. The aetiology of ram epididymitis. Onderstepoort J. Vet. Res. 47:101-107.

Jansen B.C. 1983. The epidemiology of bacterial infection of the genitalia in rams. Onderstepoort J. Vet. Res. 50:275-282.

McClure S.J. 2009. Dietary modulation of the mucosal immune response to a parasite. Immunol. Cell Biol. 87:159-166. 
Moustacas V.S., Silva T.M.A., Costa L.F., Xavier M.N., Carvalho C.A., Costa E.A., Paixao T.A. \& Santos R.L. 2013. Species-specific multiplex PCR for the diagnosis of Brucella ovis, Actinobacillus seminis, and Histophilus somni infection in rams. BMC Vet. Res 9:51.

Moustacas V.S., Silva T.M.A., Costa L.F., Carvalho C.A., Santos R.L. \& Paixao T.A. 2014. Clinical and Pathological Changes in Rams Experimentally Infected with Actinobacillus seminis and Histophilus somni. Scient. World J. 2014:241452.

Paolicchi F.A., Casaro P.A., Gimeno E.J., Kortebani L.G. \& Mazzolli A.B. 2000. Antiesperm response in rams experimentally infected with Brucella ovis. Small Rum. Res. 32:7-15.

Patlani M., Núñez A., Salas E., Díaz E., Tenorio V. \& Suárez F. 2006. Determinación de la respuesta inmune inducida por Actinobacillus seminis en el modelo murino. Memorias (Proceedings) del XX Congreso Panamericano de Ciencias Veterinarias, Santiago de Chile, Chile.

Pollock J.M. \& Welsh M.D. 2002. The $\mathrm{WC}^{+} \delta \gamma \mathrm{T}$ cell population in cattle: a possible role in resistance to intracellular infection. Vet. Immunol. Immunopathol. 89:105-114.

Porcelli S.A., Segelke B.W., Sugita M., Wilson I.A. \& Brenner M.B. 1998. The CD1 family of lipid antigen-presenting molecules. Immunol. Today 19: 362-368.
Rhind S.M. 2001. CD1-The pathology Perspective. Vet. Pathol. 38:611-619.

Russell M.W. \& Mestecky J. 2002. Humoral immune responses to microbial infections in the genital tract. Microbes Infect. 4:667-677.

Schaller A., Kuhnert P., De la Puente-Redondo V.A., Nicolet J. \& Frey J. 2000. Axp toxins in Pasteurella ceae species from animals. Vet. Microbiol. 74:365-376.

Stephen P.J. \& Hiroshi K. 1999. Gastrointestinal Lamina Propia T Cells, p.381-393. In: Ogra P.L., Mestecky J., Lamm M.E., Strober W., Bienenstock J. \& McGhee J.R. (Eds), Mucosal Immunology. 2nd ed. Academic Press, San Diego.

Van der Broek A.H.M., Huntley J.F., Mackellar A., Machell J., Taylor M.A. \& Miller H.R.P. 2005. Characterization of lesional infiltrates of dendritic cells and $\mathrm{T}$ cell subtypes during primary infestation of sheep whit Psoroptes ovis, the sheep scab mite. Vet. Immunol. Immunophatol. 105:141-150.

Walker R.L. \& Leamaster B.R. 1986. Prevalence of Histophilus ovis and Actinobacillus seminis in the tract of sheep. Am. J. Vet. Res. 47:1928-1930.

Wright S.D., Ramos R.A., Tobias P.S., Ulevitch R.J. \& Mathison J.C. 1990. CD14 a receptor for complex of lipopolysaccharide (LPS) and LPS binding protein. Science 249:1431-1433. 